\title{
Perkinsus marinus susceptibility and defense-related activities in eastern oysters Crassostrea virginica: temperature effects
}

\author{
Fu-Lin E. Chu, Jerome F. La Peyre
}

Virginia Institute of Marine Science, School of Marine Science, College of William and Mary, Gloucester Point, Virginia 23062, USA

\begin{abstract}
The relationship of potential defense-related cellular and humoral activities and the susceptibility of eastern oysters Crassostrea virginica to the parasite Perkinsus marinus were examined at 10, 15, 20 and $25^{\circ} \mathrm{C}$. Oysters were acclimated at experimental temperatures for $20 \mathrm{~d}$ and then challenged with $P$. marinus. Total hemocyte counts (TC) and percentage of granulocytes (PG) $20 \mathrm{~d}$ after temperature acclimation were higher in oysters at high than at low acclimation temperature. Higher protein $(\mathrm{P})$ and lysozyme $(\mathrm{L})$ concentrations were found in oysters at 10 and $15^{\circ} \mathrm{C}$. No significant differences in hemagglutination $(\mathrm{H})$ titers due to temperature acclimation were observed. Infection prevalence $46 \mathrm{~d}$ after challenge by $P$. marinus was $100,91,46$ and $23 \%$ respectively, for oysters at $25,20,15$ and $10^{\circ} \mathrm{C}$. Disease intensity increased with temperature. Oysters at higher temperatures had greater PG and TC and hemocyte phagocytic activity. No difference was found in TC and PG between control and challenged oysters within each temperature treatment. Bleeding may to some extent reduce TC and $\mathrm{PG}$ in oysters. $\mathrm{P}$ did not vary much among temperatures. No reduction of $\mathrm{P}$ in oysters was found due to $P$. marinus challenge and infection. L tended to be higher in oysters at lower than at higher treatment temperatures. The oysters at $10^{\circ} \mathrm{C}$ had the highest $\mathrm{L}$ concentration and lowest $P$. marinus infection. But, it is not known whether the high extracellular $\mathrm{L}$ in oysters at $10{ }^{\circ} \mathrm{C}$ is attributable to the low $P$. marinus susceptibility in these oysters. There was no significant difference in condition index (CI) between control and challenged oysters and between infected and uninfected oysters. However, CI decreased with increasing temperatures. The $\mathrm{H}$ titers were not associated with any measured variables The greater TC, PG, and phagocytic capability in oysters at higher temperatures did not result in fewer or less intense $P$. marinus infections.
\end{abstract}

\section{INTRODUCTION}

In a host-pathogen relationship, the success or failure of the pathogen in establishing infection in the host depends upon the effectiveness of the internal defense system of the host to eliminate the invading pathogen or the ability of the pathogen to avoid the host defense. It is generally accepted that immunocompetency of the host is governed by genetic factors and mediated by extrinsic environmental regimes. Compensation for excessive environmental stress can compete for energy reserves that might otherwise be available for defense mechanisms. Similarly, pathogen infectivity is genetically controlled and affected by environmental factors.
The protozoan pathogens Perkinsus marinus (Dermo) and Haplosporidium nelsoni (MSX) are the 2 most important disease organisms in eastern oysters Crassostrea virginica on the east coast of the United States. $P$. marinus has recently become the primary oysters pathogen in the lower Chesapeake Bay (Burreson 1989, 1990, Barber 1990). It kills eastern oysters mostly during late summer and early fall (Andrews 1988, Burreson 1989). The relationship between temperature and $P$. marinus incidence has been investigated since the 1950s (Mackin 1951, 1956, Andrews \& Hewatt 1957, Perkins 1966, Soniat 1985, Craig et al. 1989, Soniat \& Gauthier 1989, Crosby \& Roberts 1990 , Gauthier et al. 1990) in field and laboratory studies. The distribution and abundance of $P$. marinus in the 


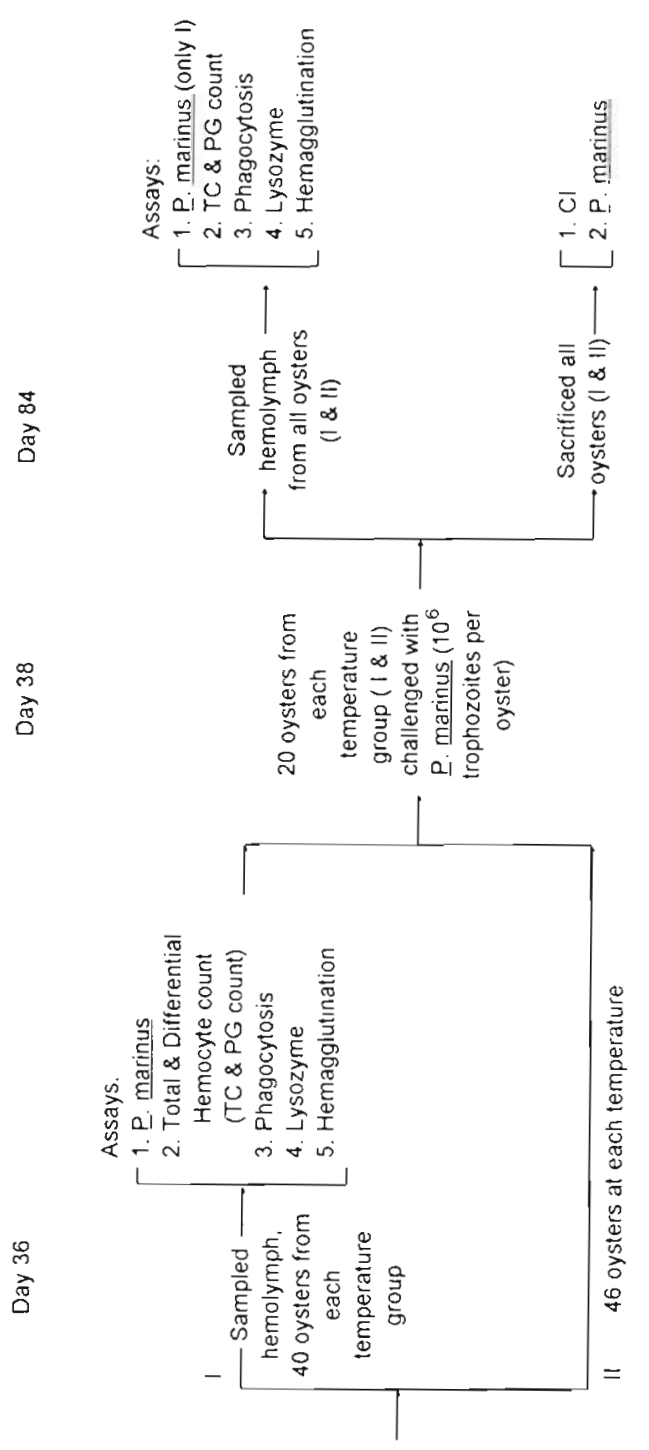

$\frac{\infty}{\pi}$

$\stackrel{\infty}{\text { तิ }}$



field are limited by temperature and salinity. Results of laboratory studies support field observation; the prevalence and intensity of $P$. marinus infection in laboratory-maintained oysters were correlated with temperature. Chu \& Greene (1989) recently described the temperature and salinity effects on in vitro culture of $P$ marinus. They reported that temperature of 28 to $30^{\circ} \mathrm{C}$ favored the in vitro development of prezoosporangia to sporulation.

The severe mortality caused by the disease has heightened interest in the study of oyster defense mechanisms and the influence of environmental factors on these mechanisms. The oyster's internal defense involves cellular (hemocytes) and humoral (e.g. lysosomal enzymes and agglutinins/lectins) components (Chu 1988. Feng 1988). Environmental temperatures significantly affect and modify cellular and humoral activities in oysters (Feng \& Canzonier 1970 , Fisher 1988, Chu \& La Peyre 1989). It has been shown that high water temperature inhibits hemocyte spreading and locomotion in Crassostred virginica. Hemolymph lysozyme has been found to vary greatly between seasons, apparently related to water temperature. Serum lysozyme levels in $C$. virginica were reported as being higher in the winter (December) than in the summer (June) (Feng \& Canzonier 1970). Similarly, lysozyme concentration was extremely low in the summer (Chu \& La Peyre 1989). The above observations suggest that the defense capacity of oysters may be influenced by temperature. The seasonal variability of environmental temperature may contribute to the observed fluctuation in disease susceptibility.

It is not known whether the suppression or change in the defense-related activities of the host is linked to its disease susceptibility. The effects of temperature on defense-related activities of the oyster and subsequent susceptibility to Perkinsus marinus have not been defined. The present study investigated the effects of temperature on the interaction between the oyster and its parasite, P. marinus, and determined whether there is a linkage between the oyster's defense activities and its susceptibility to $P$. marinus.

\section{METHODS AND MATERIALS}

Experiment. The experimental steps involved in this experiment are summarized in Fig. 1. Oysters were collected from Ross Rock, Rappahannock River (Virginia, USA), on January 29, 1991 (ambient temperature $=5.5^{\circ} \mathrm{C}$, salinity $=4 \mathrm{ppt}$ ). Oysters were cleaned of fouling organisms and maintained in estuarine water [York River water (YRW), ppt $=17.5$ ] and thereafter in $250 \mathrm{l}$ tanks at $10^{\circ} \mathrm{C}$, and algal paste (a mixture of Tahitian Isochrysis galbana and Thalassiosira pseudo- 
nana) was fed to oysters daily $\left(0.1 \mathrm{~g}\right.$ oyster $\left.{ }^{-1}\right)$. On February 5, 1991, a subsample of 30 oysters was sacrificed for condition index (CI: dry meat weight/dry shell weight $\times 100$; Lucas \& Beninger 1985) and Perkinsus marinus analysis (Ray 1952, 1966). P. marinus diagnosis in all oysters was negative. On Febuary 13, 1991, oysters were distributed to the 4 test temperatures, 10 , 15,20 and $25^{\circ} \mathrm{C}$ ( 80 oysters per temperature, 20 oysters per 381 aquarium, 4 aquaria per temperature treatment). Twenty days after the transfer to these temperatures, hemolymph was taken from 10 oysters from each aquarium at each temperature treatment to determine cellular and humoral activities, as well as possible $P$. marinus infection, using the hemolymph assay modified from Gauthier \& Fisher (1990). For subsequent description, these oysters are referred to as bled oysters to distinguish from their counterpart, nonbled oysters. After hemolymph withdrawal, oysters were labeled and placed back in the aquaria. Each aquarium thus held 10 bled and 10 nonbled oysters. Oysters at each temperature were then divided into 2 groups, control and $P$. marinus challenged. The challenged groups from each temperature treatment were inoculated with a dose of $10^{6}$ trophozoites oyster ${ }^{-1}$ in $0.1 \mathrm{ml}$ YRW. Control oysters were inoculated with $0.1 \mathrm{ml}$ of YRW. Forty-six days after challenge with $P$. marinus, hemolymph was drawn from both bled $(n=20)$ and nonbled oysters $(\mathrm{n}=20$ ) at each temperature for cellular and humoral assays. After completing hemolymph sampling, all experimental oysters were sacrificed to determine $C I$ and rectal tissues were removed for tissue assay (Ray 1952, 1966). P. marinus analysis was also conducted on individual hemolymph samples of bled oysters.

Preparation of trophozoite suspension. Trophozoite suspension was prepared as follows: Perkinsus marinus infected oyster tissues were rinsed thoroughly with filtered $(0.22 \mu \mathrm{m})$ YRW and subsequently homogenized in $0.22 \mu \mathrm{m}$ filtered YRW with a blender (Virtis, Model 23) at high speed for 2 min. The suspension was then passed through $100 \mu \mathrm{m}$ and $20 \mu \mathrm{m}$ meshes to remove oyster tissue residues. The number of trophozoites in suspension was counted using a hemocytometer and adjusted to a concentration of $10^{7}$ trophozoites $\mathrm{ml}^{-1}$.

Preparation of hemocytes and sera. Hemocytes and serum were prepared as follows: hemolymph $(1.5 \mathrm{ml})$ from individual oysters was withdrawn from the adductor muscle sinus with a syringe through notches in the shell and the hemolymph was placed in test tubes in an ice bath. Total hemocytes and number of granulocytes and agranulocytes were counted on each sample using a hemocytometer. For humoral activity measurements, serum of each hemolymph sample was separated from hemocytes through centrifugation $\left(400 \times g\right.$ at $4^{\circ} \mathrm{C}$ for $\left.10 \mathrm{~min}\right)$. Sera were withdrawn and stored in a freezer $\left(-20^{\circ} \mathrm{C}\right)$.

Hemocyte and serum factor activites. For phagocytosis measurement, hemolymph was obtained only from nonbled oysters. Pooled hemolymph samples (5 oysters sample -1 $^{-1}$ samples temperature ${ }^{-1}$ ) were assessed for phagocytosis of zymosan (yeast cell

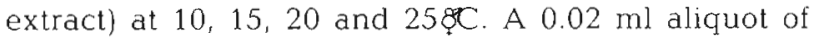
each hemolymph sample was added to a glass slide and allowed to adhere at the 4 assayed temperatures for 30 min. Two slides were prepared for each sample. A $0.02 \mathrm{ml}$ aliquot of zymosan $\left(1.0 \mathrm{mg} \mathrm{ml}^{-1}\right)$ in artificial seawater (ASW), with a salinity similar to the oystermaintaining water, was added to the hemocyte monolayer. After incubation at assayed temperatures for $1 \mathrm{~h}$, hemocyte monolayers were rinsed with ASW and fixed with Dietrich's fixative. Slides were then stained with Hemal-Stain (Hemal Stain Co., Inc., CT, USA) and attachment and phagocytosis were quantified using a light microscope. Phagocytosis and attachment of zymosan by hemocytes were determined in 5 fields (200 cells) of each slide. Results were expressed as a phagocytic index (no. of hemocytes that phagocytosed at least 1 zymosan particle/total no. of hemocytes) and phagocytic ratio (no. of zymosan particles phagocytized and associated/total no. of hemocytes).

Hemagglutinins were quantified in serum fractions of each oyster by addition of sheep erythrocytes (sheep red blood cells: SRBC) to serially diluted oyster serum in $\mathrm{U}$-well microtiter plates. The titer for a given sample was expressed as the reciprocal of the maximal dilution producing complete hemagglutination (Tripp 1966) and $\log _{2}$ transformed. Two percent SRBC suspension was prepared from SRBC stock (Becton Dickinson Microbiology System, Hunt Valley, MD, USA). Hemagglutination activity for all samples was measured using SRBC suspended in ASW of 10 ppt at room temperature. All serum samples were adjusted with distilled water to $10 \mathrm{ppt}$ prior to the assay.

Lysozyme concentration was determined spectrophotometrically according to the method of Shugar (1952) and Chu \& La Peyre (1989). Cell-free oyster serum $(0.1 \mathrm{ml})$ was added to $1.4 \mathrm{ml}$ of the bacterial Micrococcus lysodeikticus suspension and the decrease in absorbance was recorded at $450 \mathrm{~nm}$ on a Schimadzu UV 600 spectrophotometer for $2 \mathrm{~min}$ at room temperature $\left(21 \pm 1^{\circ} \mathrm{C}\right)$. All measurements were duplicated. Recorded lysozyme activities were converted to lysozyme concentration using a standard curve constructed with different concentrations of eggwhite lysozyme.

Serum protein was measured by the method of Lowry et al. (1951) using bovine albumin as a standard. A cell-free hemolymph sample $(10 \mu l)$ from individual oysters was used for the serum protein measurement. 
Perkinsus assays. Two assays, the Ray thioglycollate assay $(1952,1966)$ and the hemolymph assay (Gauthier \& Fisher 1990), were used for P. marinus diagnosis. Rectal tissue was removed from each oyster and incubated in thioglycollate medium for 4 to $5 \mathrm{~d}$. Intensity of infection was ranked from 0 (negative) to 5 (heavily infected) based on the number of stained $P$. marinus hypnospores contained in the oyster rectal tissue smear (Ray 1952, 1966). For the hemolymph assay, $0.3 \mathrm{ml}$ hemolymph from each sampled oyster was taken. The procedure modified from Gauthier \& Fisher (1990) is as follows: hemolymph samples were centrifuged at $265 \times g$ at room temperature for $10 \mathrm{~min}$. The pellets (hemocytes plus $P$. marinus trophozoites) were resuspended with $1.0 \mathrm{ml}$ of thioglycollate medium (TM) containing $0.1 \mathrm{ml}$ of $8.0 \mathrm{mg} \mathrm{ml}^{-1}$ of streptomycin and peni-cillin. Cultures were incubated at room temperature for $4 \mathrm{~d}$, then centrifuged at $265 \times \mathrm{g}$ for $10 \mathrm{~min}$ to remove TM. Pellets were resuspended with $1.0 \mathrm{ml}$ $2 \mathrm{M} \mathrm{NaOH}$ and incubated in a water bath at about $50{ }^{\circ} \mathrm{C}$ for 30 min to remove bacteria and hemocytes. Hypnospores were then washed twice with distilled water and stained with $1.0 \mathrm{ml}$ of Lugol's working solution (Ray 1952, 1:10 dilution), transferred into a separate well of a 24 -well tissue plate and examined under a Nikon inverted microscope. Intensity of infection was ranked from 0 (negative) to 5 (heavily infected) based on the number of hypnospores contained in the $1.0 \mathrm{ml}$ culture.

Statistical analysis. One-way analysis of variance (ANOVA) and a Tukey-Kramer test were used to determine similarities and differences in total hemocyte counts (TC), percentage of granulocytes (PG), protein (P) and lysozyme (L) concentrations, hemagglutinin titers $(\mathrm{H})$ and condition index $(\mathrm{CI})$ among temperature treatments and between control and challenged oysters within each temperature treatment. Differences in phagocytic ratio (PRA) and CI between temperature treatments and assay temperature were analyzed using a 2-way ANOVA followed by a Tukey-Kramer test. Data were $\log _{10}$ or arcsin transformed whenever data showed a large variance. Differences were considered statistically significant if $p<0.05$. Linear correlation was calculated among all measured variables.

\section{RESULTS}

Mean ( \pm 1 SD) TC, PG, P and L concentrations and $\mathrm{H}$ titers in hemolymph of oysters after $20 \mathrm{~d}$ acclimation (initial sampling) at $10,15,20$ and $25^{\circ} \mathrm{C}$ are shown in Table 1. Mean TC of oysters in 15,20 and $25^{\circ} \mathrm{C}$ treatments were not significantly different from each other, but were significantly higher than TC in oysters at $10^{\circ} \mathrm{C}$. PG in oysters at 10,15 and $20^{\circ} \mathrm{C}$ was similar but significantly lower than oysters at $25^{\circ} \mathrm{C}$. PG was positively correlated with temperature $(\mathrm{n}=160, \mathrm{r}=0.393$, $p<0.001$ ). Oysters at 10 and $15^{\circ} \mathrm{C}$ had similar $\mathrm{P}$ and $\mathrm{L}$ concentrations which were higher than the $\mathrm{P}$ and $\mathrm{L}$ concentrations in oysters at 20 and $25^{\circ} \mathrm{C}$. L concentrations were negatively correlated with temperature $(\mathrm{n}=160, \mathrm{r}=-0.598, \mathrm{p}<0.001)$. No significant differences in $\mathrm{H}$ titers were observed among groups. Perkinsus marinus diagnosis on hemolymph samples of acclimated oysters was negative.

Perkinsus marinus prevalence, calculated from results of the Ray tissue assay $46 \mathrm{~d}$ after initial exposure, is shown in Fig. 2. Data from bled and nonbled groups were pooled, since there was no difference in prevalence between these 2 groups. Disease prevalence was $100,91,46$, and $23 \%$ respectively, at $25,20,15$ and $10^{\circ} \mathrm{C}$. P. marinus prevalence and mean infection intensity (Fig. 3A, B) increased with temperature. Only 1 oyster from the $20^{\circ} \mathrm{C}$ nonbled control group was found

Table 1. Total (TC) and differential (PG) hemocyte counts $\left(10^{4}\right.$ cells $\left.\mathrm{ml}^{-1}\right)$, protein $\left(\mathrm{P} ; \mathrm{mg} \mathrm{m}^{-1}\right)$ and lysozyme $\left(\mathrm{L}_{i} \mu \mathrm{g} \mathrm{ml^{-1 }}\right)$ concentrations, and hemagglutination titers $\left(\mathrm{H} ; \log _{z}\right)$ in hemolymph of oysters after $20 \mathrm{~d}$ acclimation at $10,15,20$ and $25^{\circ} \mathrm{C} . \mathrm{n}=40$. Values shown represent mean $\pm 1 \mathrm{SD}$. Lines connect treatments not significantly different ( 1 -way ANOVA, SNK; TC, P and L data were $\log _{10}$ transformed; PG data were arcsin transformed. L was negatively correlated with temperature $(n=160, r=-0.598$, $p=0.001 . P G$ was positively correlated with temperature $(n=160, r=0.273, p=0.001)$

\begin{tabular}{|c|c|c|c|c|c|}
\hline \multicolumn{6}{|c|}{ Temperature $\left({ }^{\circ} \mathrm{C}\right)$} \\
\hline & 10 & 15 & 20 & 25 & $\mathrm{p}$ \\
\hline $\mathrm{TC}$ & $136.3 \pm 188.2$ & $150.6 \pm 94.4$ & $152.6 \pm 65.9$ & $170.8 \pm 104.5$ & $\mathrm{p}<0.05$ \\
\hline$P G$ & $36.2 \pm 19.0$ & $40.0 \pm 14.4$ & $4 \underline{3} .3 \pm 16.1$ & $49.2 \pm 17.4$ & $p<0.05$ \\
\hline $\mathrm{P}$ & $8.2 \pm 2.3$ & $6.6 \pm 1.3$ & $5.0 \pm 1.4$ & $5.0 \pm 1.4$ & $p<0.05$ \\
\hline $\mathrm{L}$ & $13.9 \pm 11.4$ & $\begin{array}{c}10.0 \pm 5.8 \\
(\mathrm{n}=39)\end{array}$ & $\begin{array}{l}7.3 \pm 3.2 \\
(\mathrm{n}=38)\end{array}$ & $6.3 \pm 3.1$ & $p<0.05$ \\
\hline $\mathrm{H}$ & $3.7 \pm 2.4$ & $3.6 \pm 2.4$ & $3.6 \pm 2.1$ & $4.1 \pm 2.4$ & $p>0.05$ \\
\hline
\end{tabular}




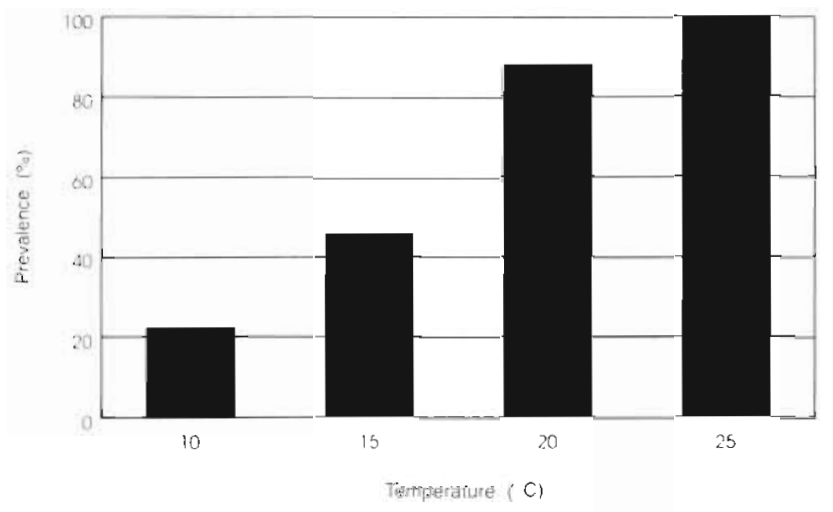

Fig. 2. Crassostrea virginica. Perkinsus marinus prevalence in oysters at $10,15,20$ and $25^{\circ} \mathrm{C} 46 \mathrm{~d}$ after challenge with $10^{6}$ trophozoites oyster 1 Data from bled and nonbled groups combined $(n=44)$

to have a light $P$. marinus infection Infection intensity determined by the hemolymph assay exhibited a linear correlation ( $n=73, r=0.764, p<0.001$ ) with the results from tissue assays. Weighted incidence (sum of diesease code numbers/number of oysters) calculated from the hemolymph and tissue assay data displayed a pattern similar to disease prevalence and infection intensity (results not shown).

TC in bled and nonbled oysters after 46 $\mathrm{d}$ exposure to Perkinsus marinus is summarized in Fig. 4. Mean TC was lowest at $10^{\circ} \mathrm{C}$ and highest at $25^{\circ} \mathrm{C}$ for both bled and nonbled groups. A significant difference was found in TC between control and challenged oysters in the bled group at $15^{\circ} \mathrm{C}$ and in the nonbled group at $20^{\circ} \mathrm{C}$. At $25^{\circ} \mathrm{C}$. TC in challenged oysters was significantly higher than in control oysters. Generally, in both control and challenged groups, mean TC appeared to be higher in nonbled oysters than in bled oysters. It is interesting to note that at $10^{\circ} \mathrm{C}$ there was a significant decrease in TC between initial and final samples (Table 1, Fig. 4).

A similar trend in PG (Fig. 5) was observed. In both bled and nonbled groups, control and challenged oysters exhibited lower PG at lower temperatures. PG at $10^{\circ} \mathrm{C}$ in all groups was significantly lower than at other temperatures. No significant difference was observed between control and challenged oysters of the bled groups; however, PG in control oysters was higher than in challenged oysters in the nonbled groups. PG of oysters in bled groups sampled at the beginning of the experiment was significantly higher than in oysters sampled at the end of the experiment; but, in nonbled groups, only oysters at $10^{\circ} \mathrm{C}, \mathrm{PG}$ was lower at the end of the experiment compared to the beginning of the experiment $(20 \mathrm{~d}$ after exposure at test temperatures, prior to Perkinsus marinus challenge).

PRA and phagocytic index (PIN) for hemocytes from each temperature treatment assayed at 10,15, 20 and $25^{\circ} \mathrm{C}$ are shown in Fig $6 \mathrm{~A}, \mathrm{~B}$. The data shown in this figure were pooled from control and challenged nonbled oysters because no significant differences in mean PRA and PIN were found between control and Perkinsus marinus challenged oysters and no effect was observed due to infection status. Subsequent sta-

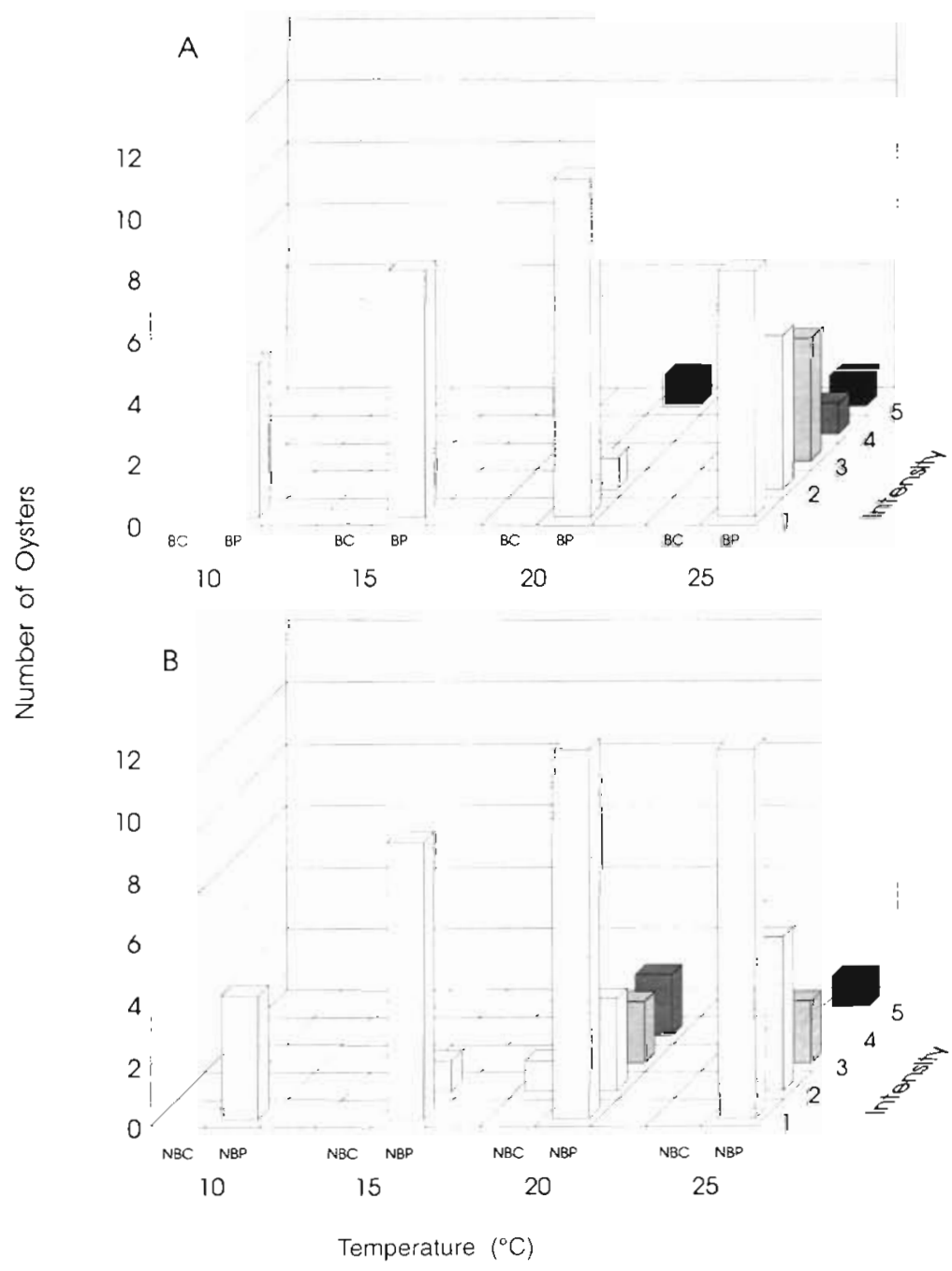

Fig. 3. Crassostrea virginica. Perkinsus marinus infection intensity in oysters $(\mathrm{n}=20)$ at $10,15,20$ and $25^{\circ} \mathrm{C}(1=$ light, $2=$ light moderate, 3 = moderate, $4=$ moderate heavy, 5 = heavy). (A) BC: bled control; $\mathrm{BP}$ : bled $P$. marinus challenged. (B) NBC: nonbled control; NBP. nonbled $P$ marinus challenged 


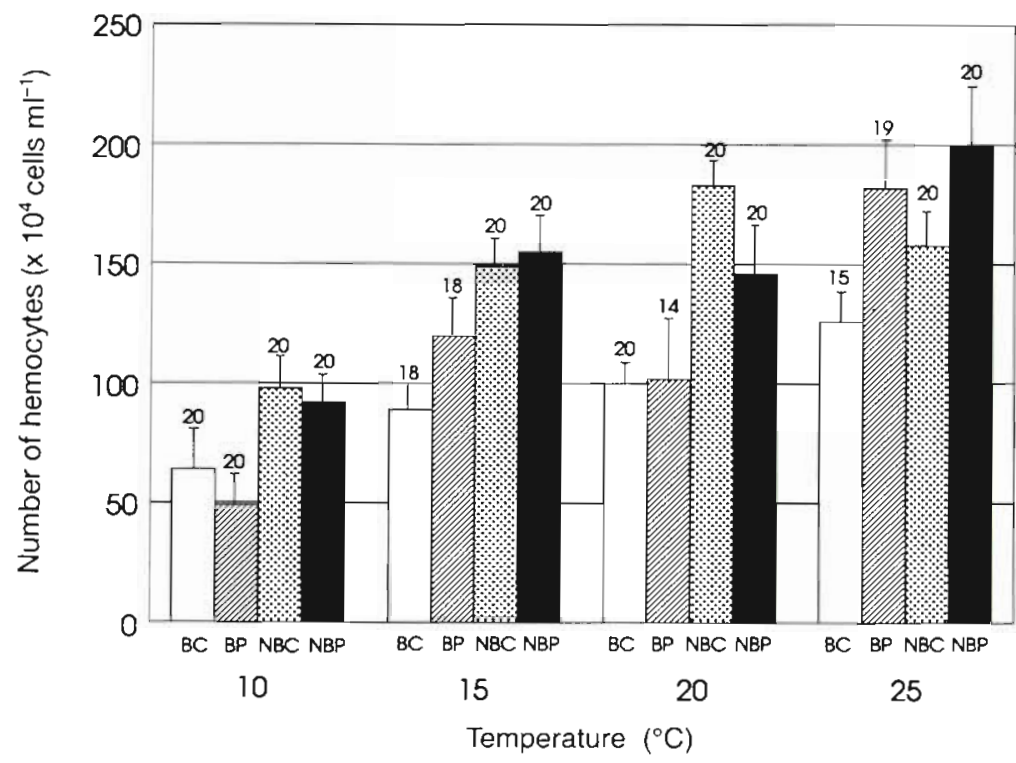

Fig. 4. Crassostrea virginica. Mean total hemocyte count (TC) + SE of oysters at $10,15,20$ and $25^{\circ} \mathrm{C} 46 \mathrm{~d}$ after Perkinsus marinus challenge ( $\mathrm{n}=14$ to 20 ; number of oysters is indicated on the top of each bar). Abbreviations as in Fig. 3

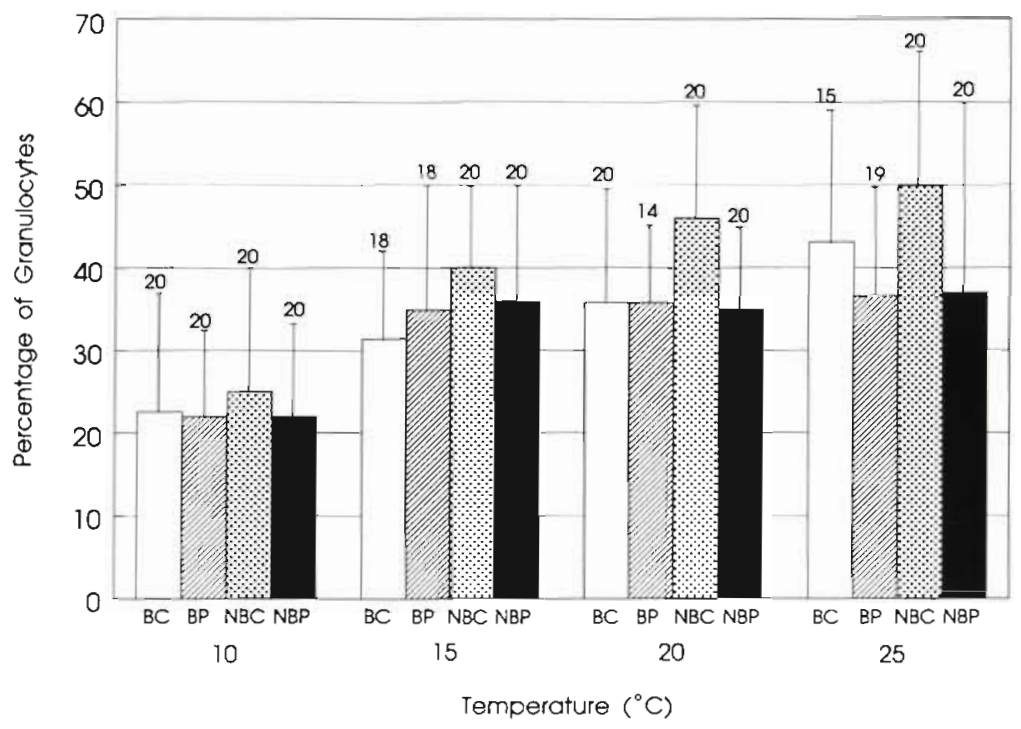

Fig. 5. Crassostrea virginica. Mean percentage of granulocytes (PG) + SD in oysters at $10,15,20$ and $25^{\circ} \mathrm{C} 46 \mathrm{~d}$ after Perkinsus marinus challenged ( $\mathrm{n}=14$ to 20 ; number of oysters is indicated on the top of each bar). Abbreviations as in Fig. 3

tistical analysis was performed on pooled data indicating significant differences $(p<0.01)$ in PRA and PIN due to treatment temperature and assayed temperature. Both PRA and PIN increased with the increase of treatment temperature from 10 to $20^{\circ} \mathrm{C}$, but declined at $25^{\circ} \mathrm{C}$. Significant interaction between assay and treatment temperatures in PIN was detected $(p<0.01)$. The oysters exposed to $15^{\circ} \mathrm{C}$ exhibited the highest
PRA at all assay temperatures tested, but the $20^{\circ} \mathrm{C}$ treatment group had the highest PIN. Within each treatment group, the highest PRA and PIN occurred at an assay temperature of $20^{\circ} \mathrm{C}$. PRA and PIN were significantly reduced when hemocytes from 20 and $25^{\circ} \mathrm{C}$ treatment groups were assayed at $10^{\circ} \mathrm{C}$.

Generally, all oysters exhibited increased hemolymph $\mathrm{L}$ concentrations at the end of the experiment compared to the beginning of the experiment (Table 1, Fig 7). In all temperature treatments, no significant difference in L concentration was observed between control and challenged groups and between infected and uninfected oysters (results not shown). Differences in mean $\mathrm{L}$ concentration among temperatures are emphasized when data from challenged and control oysters are pooled (Fig. 8). L concentration in oysters at $10^{\circ} \mathrm{C}$ was significantly higher than in oysters at other temperatures. Hemolymph $\mathrm{L}$ in oysters sampled at the end of the experiment was negatively correlated with temperature $(\mathrm{n}=299, \mathrm{r}=-0.2682, \mathrm{p}<0.001$ ) but positively correlated with $\mathrm{CI}$ ( $\mathrm{n}=295, \mathrm{r}=$ $0.2912, \mathrm{p}<0.001$ )

Hemolymph $P$ (Fig. 9) did not vary much among temperature treatments. However, when ANOVA analyses were performed on data pooled from control and Perkinsus marinus challenged oysters, results indicate that oysters, both bled and nonbled, at $10^{\circ} \mathrm{C}$ had significantly higher $\mathrm{p}$ than oysters at 15,20 and $25^{\circ} \mathrm{C}$. P level declined in oysters at 10 and $15^{\circ} \mathrm{C}$ over the course of the experiment. The $\mathrm{P}$ concentrations of challenged oysters at $25^{\circ} \mathrm{C}$, which were $100 \%$ infected with $P$ marinus, were not significantly different from control (uninfected) oysters. At 10 and $20^{\circ} \mathrm{C}, \mathrm{P}$ concentration in nonbled $P$. marinus challenged oysters was higher than in control oysters. Similarly at $20^{\circ} \mathrm{C}$, bled challenged oysters, 91 , of which were infected by $P$. marinus, had more $P$ than control oysters.

Results of ANOVA indicated that no difference existed in $\mathrm{H}$ titers (Fig. 10) in bled groups among temperatures. However, within nonbled control groups, hemagglutination at $15^{\circ} \mathrm{C}$ was significantly higher than other groups. No difference was found between control and challenged groups except in nonbled oysters at 10 and $15^{\circ} \mathrm{C}$ and in bled oysters at $25^{\circ} \mathrm{C}$. There was a trend of higher $\mathrm{H}$ in nonbled oys- 


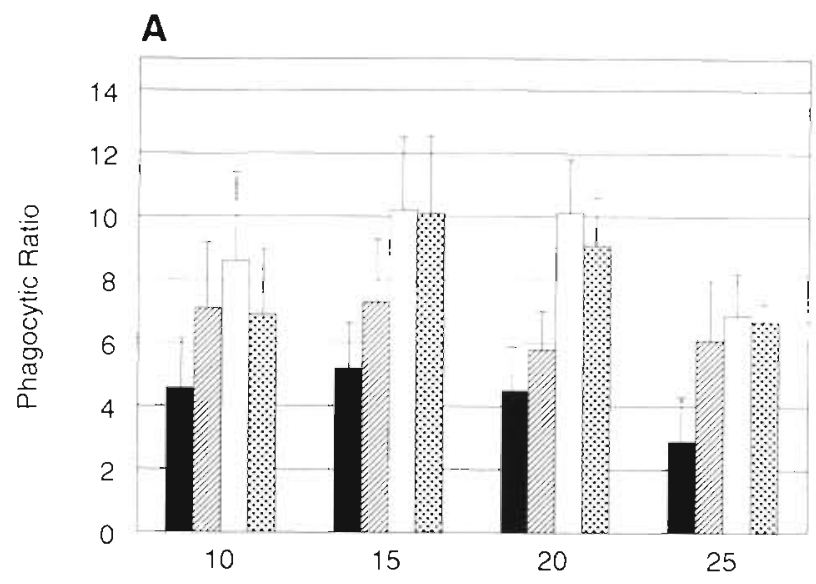

B

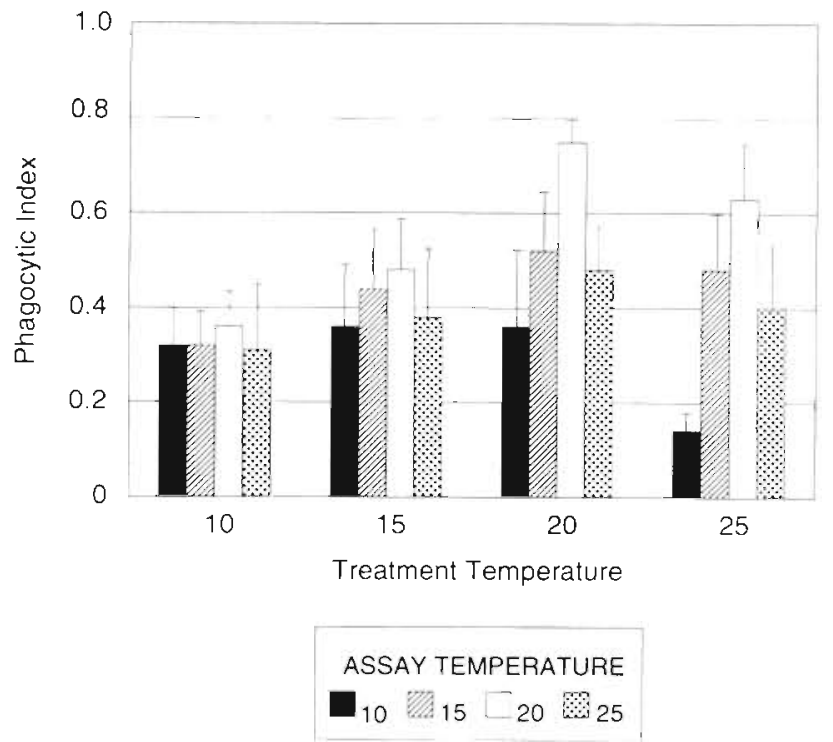

Fig. 6. Crassostrea virginica. Phagocytic ratio (PRA) and index (PIN) of hemocytes from nonbled oysters from each temperature treatment assayed at $10,15,20$ and $25^{\circ} \mathrm{C}$

ters than in bled oysters in both control and challenged groups.

CI of oysters sampled at the end of the experiment is shown in Fig. 11. In both bled and nonbled groups, no difference was found in CI between control and challenged oysters at any temperature. CI was determined to be negatively correlated with temperature (BC: bled control, $r=0.5128$; BP: bled challenged, $r=-0.6260$; NBC: nonbled control, $r=0.4095$; NBP: nonbled challenged, $r=-0.4270$ ). Oyster $C I$ decreased at the end of the experiment compared to the CI measured $8 \mathrm{~d}$ after oysters were collected.

Table 2 gives correlation coefficients between cellular and humoral measurements, oyster $\mathrm{Cl}$, parasitism and temperature in infected and uninfected oysters at the end of the experiment. Data from bled and nonbled groups were pooled and only the parameters which displayed significant correlation $(p \leq 0.05)$ are shown in the table.

\section{DISCUSSION}

The present study clearly demonstrates that disease prevalence and intensity of the parasite in oysters are positively related to test temperatures. This is consistent with previous findings in field and laboratory studies. It has been suggested that repeated bleeding of oysters may result in increased susceptibility to Haplosporidium nelsoni infection (Ford 1986b). Bleeding oysters once did not seem to affect Perkinsus marinus susceptibility; the bled and nonbled groups displayed a similar pattern of infection. Although none of the oysters ( $\mathrm{n}=30$ ) collected from the Rappahannock River initially tested positive for $P$. marinus, cryptic infections apparently existed in experimental oysters; 1 control oyster from the nonbled group at $20^{\circ} \mathrm{C}$ was found to be lightly infected by the parasite.

Temperature significantly influenced $\mathrm{TC}$ and, to some extent, PG in oysters. Higher TC and PG were observed in oysters acclimated at higher temperatures and this continued through the end of the experiment. These results could be explained in terms of a higher heartbeat rate resulting in a larger number of circulating hemocytes (Feng 1965) and/or higher production rate of hemocytes and granulocytes at higher water temperatures. We observed seasonal variation of $\mathrm{TC}$ and PG in oysters collected monthly from Deep Water Shoal of James River, Virginia, USA, corresponding to seasonal temperature (Chu et al. unpubl. results). Higher TC and PG occurred in the months of highest water temperature (e.g. June, July and August).

The positive correlation between TC and Perkinsus marinus intensity in infected oysters (Table 2) may be an indication of pathological effects in oysters. Ling (1990) also found a significant increase in hemocyte number (hemocytosis) in the hemolymph of oysters infected by Haplosporidium nelsoni. The observation of higher TC in oysters of nonbled groups than in oysters of bled groups and the significant decrease of PG in oysters of bled groups at the end of the experiment suggest that bleeding may to some extent reduce $\mathrm{TC}$ and $\mathrm{PG}$ in oysters. Prolonged low temperature exposure also reduced $\mathrm{TC}$ and $\mathrm{PG}$ in oysters. At $10^{\circ} \mathrm{C}$, both parameters were lower at the end than at the beginning of the experiment (Table 1, Figs. 4 and 5).

Phagocytosis measured in pooled hemocyte samples at the end of the experiment indicated that phagocytic activity was temperature-dependent (Fig. 6). A temperature increase from 10 to $20^{\circ} \mathrm{C}$ heightened phagocytic activity. Increased temperature was reported to 


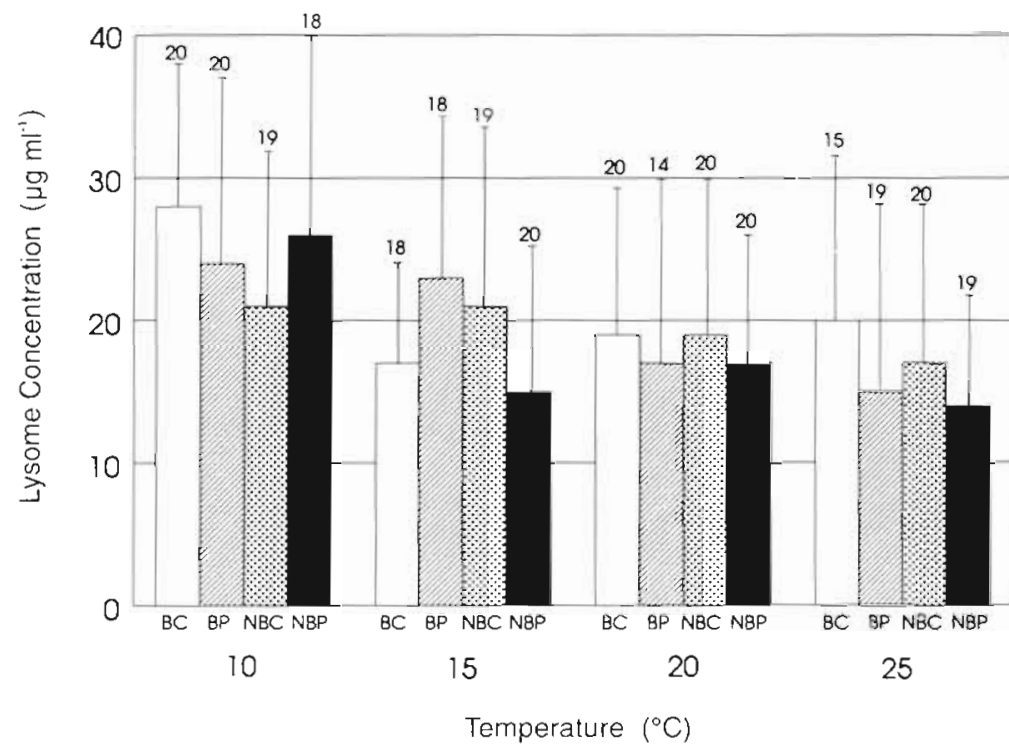

Fig. 7 Crassosirea virginica. Mean hemolymph lysozyme concentration (L) $+\mathrm{SD}$ of oysters at $10,15,20$ and $25^{\circ} \mathrm{C} 46 \mathrm{~d}$ after Perkinsus marinus challenge ( $n=14$ to 20 ; number of oysters is indicated on the top of each bar) Abbreviations as in Fig. 3

enhance hemocyte spreading and locomotion of the eastern oyster (Fisher 1988). Decline of hemocyte activity at temperatures higher than $20^{\circ} \mathrm{C}$ was not observed in Fisher's study. Rate of hemocyte locomotion was highest at the highest experimental temperature of $26^{\circ} \mathrm{C}$. However, hemocyte spreading capacity was found to correspond with annual temperature cycle: rapid in late fall, winter and early spring and slow from late spring to early fall (Fisher et al. 1989). In the present study, less effective phagocytic activity at a temperature of $25^{\circ} \mathrm{C}$, which favors parasite development, may be one of the reasons why $100 \%$ of the challenged oysters are infected at $25^{\circ} \mathrm{C}$ with the highest disease intensity.

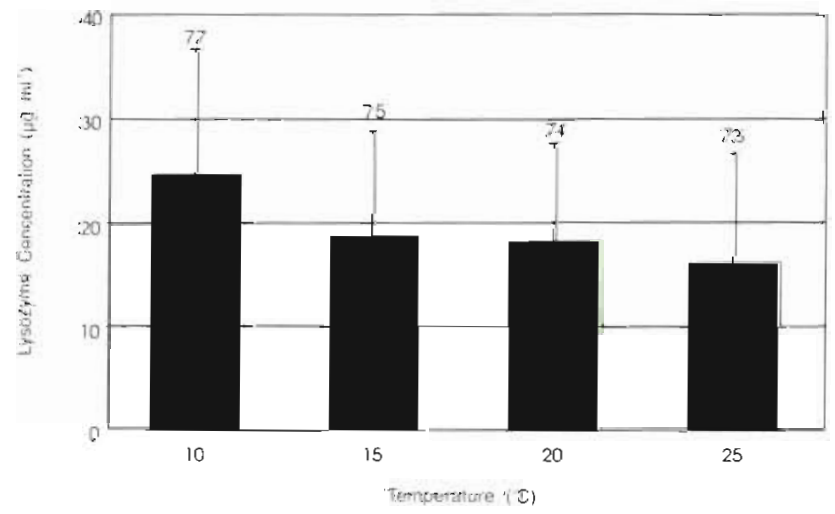

Fig. 8. Crassostrea virginica. Mean hemolymph lysozyme + $\mathrm{SD}$ in oysters at $10,15,20$ and $25^{\circ} \mathrm{C}$. Data from each temperature were pooled $(n=80)$
It is believed that hemocytes in bivalves are the primary line of defense (Cheng 1981, Feng 1988). Results of this study indicate that the ability of hemocytes to defend oysters against Perkinsus marinus may be compromised at higher temperatures. At a higher temperature, oysters had a greater number of circulating hemocytes and phagocytic capability but did not have lower prevalence or less intense P. marinus infections. We also observed in vitro phagocytosis of $P$. marinus trophozoites by hemocytes from eastern oysters at a temperature of $15 \pm 1^{\circ} \mathrm{C}$ and at a salinity of about 20 ppt (La Peyre et al. unpubl.). Electron microscopy, however, revealed that only $25 \%$ of the phagocytosed trophozoites were killed. Apparently, oyster hemocytes are able to recognize the parasite $P$. marinus and intracellular killing may have occurred, but the rate of killing may not be sufficient to cope with multiplication of the parasite because of its high metabolic activity.

The observed higher $\mathrm{L}$ concentration in oysters acclimated at 10 and $15^{\circ} \mathrm{C}$ for $20 \mathrm{~d}$ that remained high throughout the whole experiment is a result of temperature effect, not a response to Perkinsus marinus challenge and/or infection, since no significant difference in $\mathrm{L}$ concentration was observed between control and challenged or between infected an uninfected oysters. A defense role has been suggested for lysosomal enzymes in vertebrates and invertebrates (Ingram 1980, Jolles \& Jolles 1984). The significant defense role of lysosomal enzymes in bivalve molluscs has also been documented (e.g. McDade \& Tripp 1967a, b, Cheng 1978, Cheng 1979, Huffmann \& Tripp 1982, Moore \& Gelder 1985), and reviewed and dicussed by Cheng (1983a, b, c) and Chu (1988). L concentrations in oysters also decreased with increased salinity (Chu et al. unpubl.). However, it is not known whether extracelluar L plays a role in oyster defense through extracellular deterioration of the parasite when its activity is already reduced at low temperature and low salinity (Chu \& Greene 1989). It is also unknown whether intracellular $\mathrm{L}$ increases in the same manner as extracelluar $\mathrm{L}$ in oysters at low temperature or at low salinity. Moreover, the lytic activity of L on many species of bacteria has been demonstrated (see reviews by Cheng 1983 and Chu 1988) but its effect on a pathogenic parasite, such as P. marinus, has not been tested.

The ability to agglutinate latex beads was greater in Haplosporidium nelsoni resistant oysters than in $H$. nelsoni susceptible oysters, and as infection intensified in susceptible oysters, agglutination of latex beads de- 
clined (Ling 1990). Decrease of bacterial agglutination was also observed in $H$. nelsoni susceptible oysters (Tamplin \& Fisher 1989), but that is not the case with $\mathrm{H}$ measured in oysters in this study. H titer was the only parameter unaffected by the temperature change imposed upon the oysters and did not vary with the condition of the oysters. However, bleeding may reduce hemagglutinins in oysters.

The low hemolymph $\mathrm{P}$ in oysters at high temperatures may be due to relatively high metabolic activity at high temperature and/or consumption of protein for energy and cell e.g. hemocyte production. It is not certain, at this stage, whether or not the lower $\mathrm{P}$ concentration of oysters at 10 and $15^{\circ} \mathrm{C}$ at the end of the experiment is attributable to the low feeding rate of these oysters at persistent low temperature.

Oysters infected by Haplosporidium nelsoni had low hemolymph and tissue $\mathrm{P}$ (Ford 1986a, b, Barber et al. 1988, Ling 1990). In the present study, hemolymph $P$ concentrations in oysters were not affected by Perkinsus marinus infections. But, it should be noted that hemolymph $P$ decreased only when oysters were heavily infected by $H$. nelsoni (Ling 1990) and P reduction in tissues occurred only in oysters systematically infected with $H$. nelsoni (Barber et al. 1988). Most ( $88 \%$ ) of the infected oysters in this study were only lightly infected (intensity: 1 to 2 ) with the parasites, so depletion of $\mathrm{P}$ may not have occurred in these oysters.

The negative correlation between CI and infection intensity in infected oysters (Table 2) is analogous to results reported by Paynter \& Burreson (1991). The low CI in oysters at $25^{\circ} \mathrm{C}$ may be due to higher metabolism. It is not known whether the decrease of $\mathrm{CI}$ in oysters at the end of the experiment compared to the $\mathrm{CI}$ of the oysters $8 \mathrm{~d}$ after collection is due to nutritional stress and/or to the stress of a confined environment.

In summary, prevalence and intensity of Perkinsus marinus infection in oysters are positively related to temperature. Temperature also affected the physiology of the oysters. Exposing oysters from an ambient temperature of $5.5^{\circ} \mathrm{C}$ to test temperatures of $10,15,20$ and $25^{\circ} \mathrm{C}$ for $20 \mathrm{~d}$ induced significant differences in TC, PG and hemolymph $\mathrm{P}$ and L concentrations among

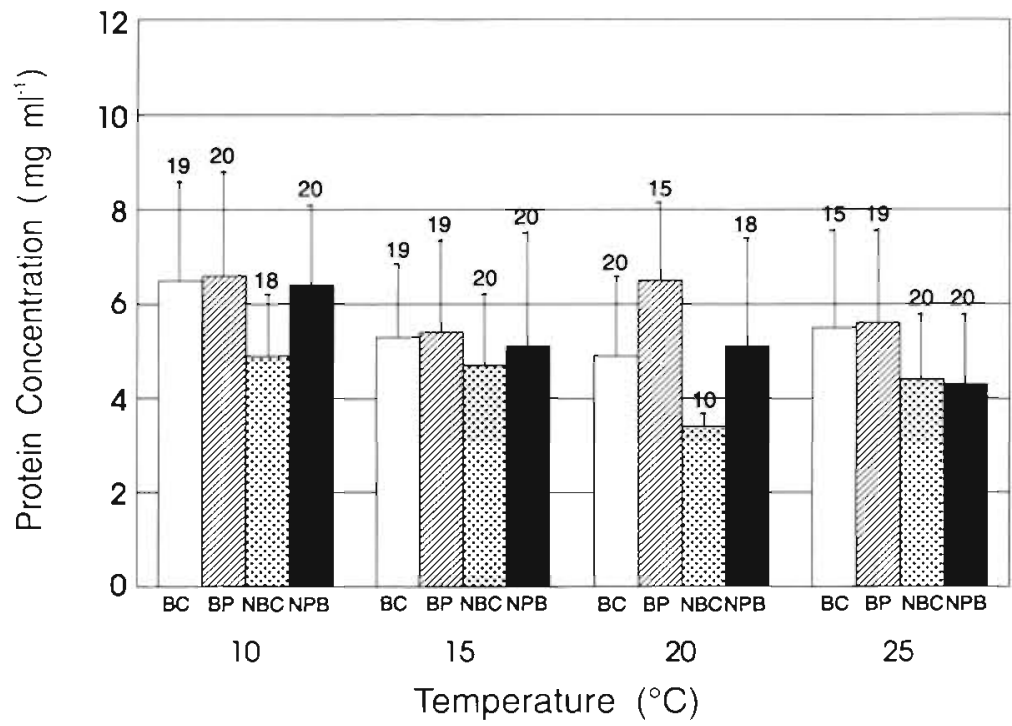

Fig. 9. Crassostrea virginica. Mean hemolymph protein concentration (P) + $\mathrm{SD}$ in oysters at $10,15,20$ and $25^{\circ} \mathrm{C} 46 \mathrm{~d}$ after Perkinsus marinus challenged ( $\mathrm{n}=15$ to 20 ; number of oysters is indicated on the top of each bar). Abbreviations as in Fig. 3

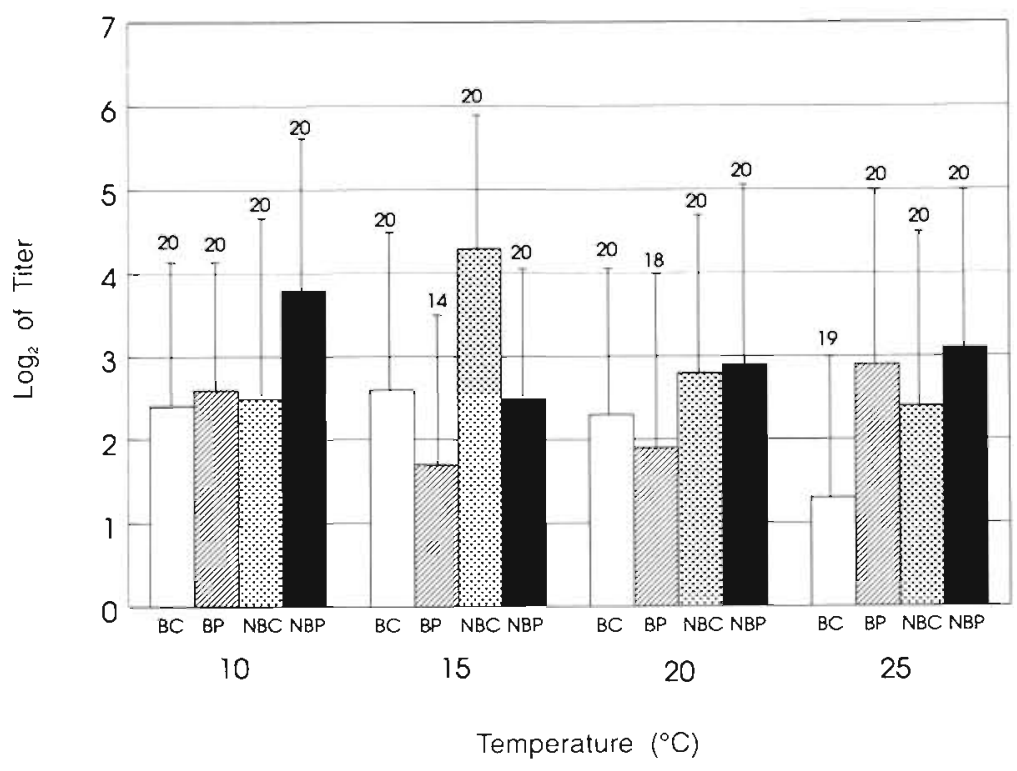

Fig. 10. Crassostrea virginica. Mean hemagglutination titer $(\mathrm{H})$ in oysters at $10,15,20$ and $25^{\circ} \mathrm{C} 46 \mathrm{~d}$ after Perkinsus marinus challenged ( $\mathrm{n}=14$ to 20; number of oysters is indicated on the top of each bar). Abbreviations as in Fig. 3

certain treatment groups. These differences persisted throughout the experiment. Oysters with a greater number of circulating hemocytes and phagocytic capability at a higher temperature did not have fewer or less intense $P$. marinus infections. The oysters at $10^{\circ} \mathrm{C}$ which had the lowest $P$. marinus prevalence had the highest extracellular L concentration, suggesting the $\mathrm{L}$ 


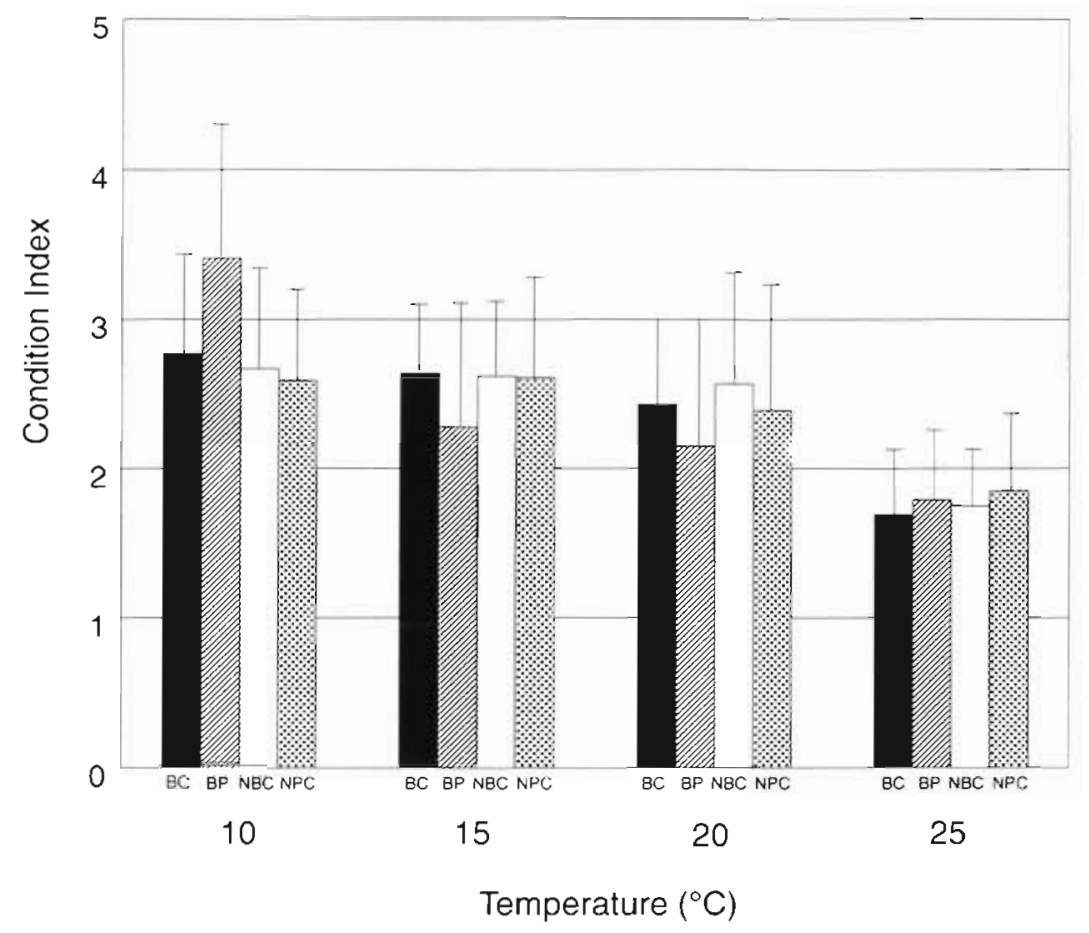

Fig. 11. Crassostrea virginica. Mean condition index $(\mathrm{CI})+\mathrm{SD}$ of oysters sampled at the end of the experiment from $10,15,20$ and $25^{\circ} \mathrm{C}$ treatment groups $(n=15$ to 20$)$. Abbreviations as in Fig. 3

Table 2. Correlation coefficients between cellular parameters, humoral parameters, oyster condition indices, infection intensity and temperatures of uninfected and infected oysters. TC: total hemocyte counts; PG: \% of granulocytes; L: lysozyme; CI: condition indices; PI: infection intensity of $P$. marinus. [Only significant correlations $(p<0.05)$ are shown]

\begin{tabular}{|c|c|c|c|c|c|c|c|c|c|c|c|}
\hline & \multicolumn{5}{|c|}{ Uninfected oysters } & \multicolumn{6}{|c|}{ Infected oysters } \\
\hline & $\mathrm{TC}^{\mathrm{a}}$ & $\mathrm{DC}^{a}$ & $\mathrm{P}^{\mathrm{c}}$ & $\mathrm{L}^{\mathrm{b}}$ & $\mathrm{CI}^{\mathrm{d}}$ & $\mathrm{TC}^{\mathrm{d}}$ & $D C^{d}$ & $\mathrm{P}^{\mathrm{e}}$ & $L^{e}$ & $\mathrm{CI}^{\mathrm{d}}$ & $\mathrm{PI}^{\mathrm{d}}$ \\
\hline Temperature $\left({ }^{\circ} \mathrm{C}\right)$ & 0.34 & 0.51 & -0.27 & -0.20 & -0.46 & 0.35 & 0.28 & -0.20 & -0.27 & -0.57 & 0.38 \\
\hline $\mathrm{TC}$ & - & 0.65 & -0.19 & - & -0.22 & & 0.17 & -0.29 & - & -0.24 & 0.33 \\
\hline DC & - & - & -0.31 & -0.16 & -0.24 & - & - & - & - & - & - \\
\hline $\mathrm{H}^{\dagger}$ & - & - & - & - & - & - & - & - & - & - & - \\
\hline $\mathrm{P}$ & - & -0.31 & - & - & 0.15 & - & - & - & 0.18 & - & - \\
\hline $\mathrm{L}$ & - & -0.16 & - & - & 0.30 & - & - & - & - & 0.26 & -0.26 \\
\hline $\mathrm{CI}$ & - & -0.24 & 0.15 & 0.30 & - & - & - & - & 0.26 & - & -0.26 \\
\hline
\end{tabular}

may be one of the factors attributing to the low P. marinus susceptibility in these oysters. However, at this time, the role of extracellular L in the oyster's defense is completely unknown and remains to be examined.

Acknowledgements. This work was supported in part by the National Marine Fisheries Service, the Oyster Disease Research Program (grant no. NA90AA-D-FM739), NOAA and in part by the Jeffress Memorial Trust, Virginia. The authors thank Dr R. Mann for his kindness in making the spectrophotometer in his laboratory available for our use, L. Ragone for data analysis and graphic work, C. Burreson and D. Abernathy for technical assistance, K. Walker and R. B. Barber for assistance in oyster collection, Dr J. Kirkerly for his advice on statistical analysis of experimental data, Drs $B$. Barber and $M$. Roberts for review of the earlier draft of the manuscript and the 3 anonymous reviewers of the submitted manuscript. Contribution no. 1790 from the Virginia Institute of Marine Science, College of William and Mary.

\section{LITERATURE CITED}

Andrews, J. D., Hewatt, W. G. (1957). Oyster mortality studies in Virginia. II. The fungus disease caused by Dermocystidum marinum in oysters of the Chesapeake Bay. Ecol. Monogr. 27(1): 1-25

Andrews, J. D. (1988). Epizootiology of the disease caused by the oyster pathogen Perkinsus marinus and its effects on the oyster industry. Spec. Publ. Am. Fish. Soc. 18: 47-63

Barber, J. B., Ford, S. E., Haskin, H. H. (1988). Effects of the parasite MSX (Haplosporidium nelsoni) on oyster 
(Crassostrea virginica) energy metabolism: IJ. Tissue brochemical composition. Comp. Biochem. Physiol. 91A: $603-608$

Barber, J. B. (1990). Status of the public oyster fishery of Virginia. Marine Resource Report 90. Virginia Institute of Marine Science, Gloucester Point

Burreson, E. M. (1989). Prevalence of the major oyster diseases of Virginia waters - 1988. A summary of the annual monitoring program. Marine Resource Report 89-1, Virginia Institute of Marine Science, Gloucester Point

Burreson, E. M. (1990). Status of the major oyster dieseases in Virginia-1989. A summary of the annual monitoring program. Marine Resource Report 90-1, Virginia Institute of Marine Science, Gloucester Point

Cheng, T. C. (1978a). The role of lysosomal hydrolases in molluscan cellular response to immunologic challenge. Comp. Pathobiol. 4: 59-71

Cheng, T. C. (1978b). The role of hemocytic hydrolases in the defense of molluscs against invading parasites. Haliotis 8 ; 193-209

Cheng, T. C. (1981). Bivalves. In: Radcliffe, N. A., Rowley, A. $F$. (eds) Invertebrate blood cells. Academic Press, New York, p. 233-300

Cheng. C. T (1983a). The role of lysosomes in molluscan inflammation. Am. Zool. 23: 129-144

Cheng, C. $T$ (1983b). Triggering of immunologic defense mechanisms of molluscan shellfish by biotic and abiotic challenge and its application. J mar Technol. Soc. 17: $18-25$

Cheng, C. T (1983c). Internal defense mechanisms against invading microorganisms. Trans. Am. microsc. Soc. 102 : $185-193$

Chu, F.-L. E. (1988). Humoral defense factors in marine bivalves. Spec. Publ. Am. Fish. Soc. 18: 178-188

Chu, F.-L. E., Greene, K. H. (1989). Effect of temperature and salinity on in vitro culture of the oyster pathogen, Perkinsus marinus (Apicomplexa: Perkinsea). J. Invertebr Pathol. 53: 260-268

Chu, F.-L. E., La Peyre, J. F. (1989). Effect of environmental factors and parasitism on hemolymph lysozyme and protein of American oysters (Crassostrea virginica). J. Invertebr. Pathol 54: 224-232

Craig, A., Powell, E. N., Ray, R. R., Brooks, J. M. (1989). Distribution of Perkinsus marinus in Gulf Coast oyster populations. Etuaries 12(2): 82-91

Crosby, M. P., Roberts, C. F. (1990). Seasonal infection intensity cycle of the parasite Perkinsus marinus (and an absence of Haplosporidium spp.) in oysters from a South Carolina salt marsh. Dis. aquat. Org. 9:149-155

Feng, S. Y (1965). Heart rate and leucocyte circulation in Crassostrea virginica. Biol. Bull. 128: 198-210

Feng, S. Y., Canzonier, W. J. (1970). Humoral responses in the American oyster (Crassostrea virginica) infected with Bucephalus sp. and Minchinia nelsoni. Spec. Publ. Am Fish. Soc. 5: 497-510

Feng, S. Y (1988). Cellular defense mechanisms of oysters and mussels. Spec. Publ. Am. Fish. Soc. 18: 153-168

Fisher, W. S. (1988). Environmental influence on bivalve hemocyte function. Spec. Publ. Am. Fish. Soc. 5: 497-510

Fischer, W. S., Chintala, M. M., Moline, M. A. (1989). Annual variation for estuarine and oceanic oyster Crassostrea virginica Gmelin hemocyte capacity. J. exp. mar. Biol. Ecol. 127: $105-120$

Ford, S. E. (1986a). Comparison of hemolymph proteins in resistant and susceptible oysters, Crassostrea virginica, exposed to the parasite Haplosporidium nelsoni (MSX). J. Invertebr. Pathol 47: 283--294
Ford, S. E. (1986b). Effect of repeated hemolymph sampling on growth. mortality, hemolymph protein and parasitism of oysters, Crassostrea virginica. Comp. Biochem. Physiol. 85A: $465-470$

Gauthicr, J. D., Soniat, T M., Rogers, J. S. (1990). A parasitological survey of oysters along salinity gradients in coastal Louisiana. J. Wid Aquacult. Soc. 21: 105-115

Gauthier, J. D., Fisher, W. S. (1990). Hemolymph assay for djagnosis of Perkinsus marinus in oysters Crassostrea vurginica (Gmelin, 1791). J. Shellfish Res. 9: 367-372

Huffman, J. E., Tripp, M. R. (1982). Cell types and hydrolytic enzymes of soft shell clam (Mya arenaria) hemocytes. J. Invertebr. Pathol. 40: 68-74

Ingram, G. A. (1980). Substances involved in the natural resistance of fish to infection - a review. Journal of Fisheries Biology 16: 23-60

Jolles, P., Jolles, J. (1984). What is new in lysozyme research? Always a model system, today as yesterday. Mol. cell. Biochem. 63: 165-189

La Peyre, J. F., Chu, F.-L. E., Ragone, L. M. (1989). The effect of salinity and Perkinsus marinus infection on some immunological parameters of the oyster Crassostrea virginica (abstract). J. Shellfish Res. 8: 469

Ling, W.-J. (1990). Cellular and humoral responses of resistant and susceptible oysters, Crassostrea virginica, to the infection of Haplosporidium nelsoni (MSX). M.S. thesis, Univ. of Connecticut

Lowry, O. H., Rosebrough, N. J., Farr, A. L., Randall, R. J. (1951). Protein measurement with the Folin phenol reagent. J. biol. Chem. 193: 265-275

Lucas, A., Beninger, P. G. (1985). The use of physiological condition index in marine bivalve aquaculture. Aquaculture 44: $187-200$

Mackin, J G. (1951). Histopathology of infection of Crassostrea virginica (Gmelin) by Dermocystidium marinum Mackin, Owen and Collier Bull. mar Sci. Gulf Caribb. 1. $72-87$

Mackin, J. G. (1956). Dermocystidium marinum and other microorganisms in Louisiana. Proc. Natl Shellfish. Ass. 46: $116-133$

McDade, J. E., Tripp. M. R. (1967a). Lysozyme in the hemolymph of the oyster, Crassostrea virginica. J. Invertebr. Pathol. 9: 531-535

McDade, J. E., Tripp, M. R. (1967b). Lysozyme in oyster mantle mucus. J. Invertebr. Pathol. 9: 581-582

Moore, C. A., Gelder, S. R. (1985). Demonstration of lysosomal enzymes in hemocytes of Mercenaria mercenaria (Mollusca: Bivalvia). Trans. Am. microsc. Soc. 104: 242-249

Paynter, K. T., Burreson, E. M. (1991). Effects of Perkinsus marinus infection in the eastern oyster, Crassostrea virginica. II. Disease development and impact on the growth rate at different salinities. J. Shellfish Res. 10: 425-431

Perkins, F. O. (1966). Life history studies of Dermocystidium marinum, an oyster pathogen. Ph.D. dissertation, Florida State University

Ray, S. M. (1952). A culture technique for the diagnosis of infections with Dermocystidium marinum Mackin, Owen and Collier in oysters. Science 116: 360-361

Ray, S. M. (1966). A review of a culture method for detecting Dermocystidium marinum with suggested modifications and precautions. Proc. Natl. Shellfish. Ass. 54: 55-80

Shugar, D. (1952). The measurement of lysozyme activity and the ultra-violet inactivation of lysozyme. Biochim. Biophys. Acta 8: 302-309

Soniat, T M. (1985). Changes in levels of infection of oysters infected by Perkinsus marinus, with special reference to 
the interaction of temperature and salinity upon parasitism. Northwest Gulf Science 7: 171-174

Soniat, T. M. Gauthier, J. D. (1989). The prevalence and intensity of Perkinsus marinus from the mid northern Gulf of Mexico, with comments on the realtionship of the oyster

Responsible Subject Editor: A. K. Sparks, Seattle, Washington, USA parasite to temperature and salinity. Tulane Stud. Zool. Bot. 27(1). 21-27

Tripp, M. R. (1966). Hemagglutinin in the blood of the oyster, Crassostrea virginica. J. Invertebr. Pathol. 8: $478-484$

Manuscript first received: September 18, 1992

Revised version accepted: March 1, 1993 